\title{
Treatment of geriatrics lymphedema with shockwave therapy
}

\author{
S Michelini ', M Cardone, A Failla, G Moneta, A Fiorentino, F Cappellino \\ From de Senectute: Age and Health Forum \\ Catanzaro, Italy. 5-7 December 2009
}

\section{Background}

The radial shockwaves are pneumatically generated and emitted at the tip of the applicator and coupled into the human tissue, up to a depth of up to $35 \mathrm{~mm}$. The effects on the tissue are: increasing of metabolic processes, antiphlogistic and vasodilatation effects and neoangiogenesis with correlate increase of the fluid transport.

\section{Materials and methods}

The AA. treated 72 patients affected by primary (25) or secondary (47) lymphedema of upper and lower limbs (47 females and 25 males). Admission criteria: age between 70 and 85, complaints lasting more 1 than year with associated localized or diffuse tissue fibrosis. Exclusion criteria: specific therapy over the past 7 days, pregnancy, coagulation disorders, acute phlogosis.

Patients were treated for 10 sessions, $2.500-3.500$ impulses each (in function of the extension at the fibrotic area). The energy flow density during treatment was equal to a working pressure of 2 bars. About $3,5 \mathrm{~cm}$. depth on the suprafascial tissue. Treatment frequency was $4 \mathrm{~Hz}$ in multiple shock modality. Local anaesthesia was never used.

\section{Results}

Patients were evaluated 2 weeks and 1 month after treatment. They show an average decrease of the $26 \%$ of the circumference of the limb and a subjective and objective reduction of tissue consistence, above all in fibrotic areas.

Side effects such as local irritation were observed; petechia, hematomas, swelling and low pain 24-36 hours after treatment. Only in 1 patient the suspension of treatment was required. The high resolution echography demonstrated a medium reduction of the skin and

San Giovanni Battista Hospital, Rome, Italy epifascial thickness of $32 \%$, corresponding to the clinical observations.

\section{Conclusions}

This kind of shock wave therapy is very useful in primary and secondary lymphedema, not only for the decreasing of the limb volume, but above all for the treatment of the fibrotic areas. The technique is easy to apply and can be performed both by the physician as by the physiotherapist. There are no contraindications to the application. The tecnique can be associate with the other manual and mechanical treatment used for the lymph-drainage.

Published: 19 May 2010

\section{References}

1. Michelini S, Failla A, Moneta G, Zinicola V, Macaluso B, Cardone M, Antonucci D: Treatment of Lymphedema with shockwave therapy: preliminary study. The European Journal of Lymphology and related problems. 2007, 17(51):29.

2. Ammendola $A$, et al: Effects of unfocussed shockwave treatment in human soft tissue: preliminary study. 4 th Congress of the International Society for Musculoskeletal Shockwave therapy. Berlin 2001.

doi:10.1186/1471-2318-10-S1-A105

Cite this article as: Michelini et al:: Treatment of geriatrics lymphedema with shockwave therapy. BMC Geriatrics 2010 10(Suppl 1):A105.

Submit your next manuscript to BioMed Central and take full advantage of:

- Convenient online submission

- Thorough peer review

- No space constraints or color figure charges

- Immediate publication on acceptance

- Inclusion in PubMed, CAS, Scopus and Google Scholar

- Research which is freely available for redistribution

Submit your manuscript at www.biomedcentral.com/submit Biomed Central 